\title{
Sosyal Bilgiler ve Sınıf Eğitimi Öğretmen Adaylarının Gözünden Vatandaşlık Eğitimi: Nitel Bir Çalışma*
}

\author{
Ufuk ŞİMŞEK ${ }^{1}$, Fatih TIKMAN², Esat YILDIRIM³ ${ }^{3}$, Mehmet ŞENTÜRK ${ }^{4}$ \\ Doç.Dr, Atatürk Üniversitesi, ufuk@atauni.edu.tr \\ Arş.Gör, Kilis 7 Aralk Üniversitesi, fatibtikman@kilis.edu.tr \\ Arș.Gör, Kilis 7 Aralı. Üniversitesi, esatyildirim@kilis.edu.tr \\ Arș.Gör, Kilis 7 Aralı.Üniversitesi, senturk@_kilis.edu.tr
}

DOI: http://dx.doi.org/10.14582/DUZGEF.1871

\begin{abstract}
ÖZ
$\mathrm{Bu}$ çalışmanın amacı sınıf ve sosyal bilgiler öğretmen adaylarının vatandaşlık ve vatandaşlık eğitimi hakkındaki görüşlerini ortaya koymaktır. Bu araştırmanının çalışma grubunu 40 sınıf öğretmeni ve 35 sosyal bilgiler öğretmeni adayı olmak üzere toplam 75 öğretmen adayı oluşturmaktadır. Veri toplama aracı olarak yarı yapılandırılmış mülakat formu kullanılmıştır. Mülakat formu oluşturulurken 10 soru hazırlanmış, uzman görüşü ve yapılan pilot uygulama sonucunda mülakat formunda yer alan soru sayısı 6'ya düşürülmüştür. Çalışma, betimsel tarama modelinde nitel bir araştırmadır. Araştırmada elde edilen verilerin analizinde içerik analizinden yararlanılmıștır. Araştırmanın sonucunda şu verilere ulaşılmışıı. Öğretmen adaylarının vatandaşlıkla ilgili konularda çoğunlukla kendilerini yetersiz olarak gördükleri göze çarpmaktadır. Yetersiz gören öğretmen adaylarının çoğunluğu bu yetersizliklerinin vatandaşlık baklarmm ve bukuk kurallarm bilmemelerinden, bilgi eksikliğinden, gördükleri eğitimden verim alamadıklarndan ve gördükleri vatandaşlik eğitiminin günlük yaşamla ilişkilendiremediğinden kaynakladığını söylemişlerdir. Öğretmen adayları vatandaşıı eğitimiyle ilgili derslerinde daha çok dramadan, günlïk hayatla ilişkilendirmeye yönelik etkinliklerden, somutlașttrmaya yönelik etkinliklerden, film ve videolardan yararlanacaklarını ifade etmişlerdir. Öğretmen adaylarının çoğunluğu eğitim hayatları boyunca aldıkları vatandaşlık eğitiminin etkililiğinin yetersiz olduğuna dikkat çekmişlerdir. Araşıırma sonuçlarının, Türkiye'de vatandaşlık eğitiminin etkililiğinin arttırılması noktasında uygulayıcılar ve araştırmacılar için yol gösterici olacağı düşünülmektedir.
\end{abstract}

Anahtar Kelimeler: Vatandaşlık, vatandaşlık eğitimi, sosyal bilgiler eğitimi, sınıf eğitimi

\section{The Views of Pre-Service Social Studies Teachers and Pre-Service Classroom Teachers about Citizenship Education: A Qualitative Study}

\begin{abstract}
The aim of this study is to reveal the opinions of pre-service classroom teacher and pre-service social studies teacher about citizenship and citizenship education. The sample of this study consists of 40 pre-service classroom teacher and 35 pre-service social studies teacher (totally 75 pre-service teachers). In the research, semi-structured interview form was used as a data collection. Ten questions were prepared while preparing the interview form then the number of questions has been reduced to 6 with expert opinion and pilot scheme. The study is a qualitative research in the descriptive survey model. As a result of the study, the following has been reached. Most pre-service teachers emphasized the concepts of belonging, right, responsibility, duty, freedom and loyalty when defining citizenship. Preservice teachers often regard themselves as inadequate in matters related to citizenship. The majority of pre-service teachers who see it as inadequate have said that their inadequacy is due to their lack. of knowledge of civil rights and legal rules, lack of information, inefficient education, and citizenship education does not relate to daily life. Pre-service teachers mentioned that they would benefit more from drama, activities for linking to daily life, activities for concrete activities, films and videos in their courses related to citizenship education. Most of the pre-service teachers pointed out that the citizenship education they have taken during their education life is ineffective. It is thought that the results of the research will guide practitioners and researchers to increase the effectiveness of citizenship education in Turkey.
\end{abstract}

Keywords: Citizenship, citizenship education, social studies teacher, classroom teacher.

\footnotetext{
* Hazırlanan bu araştırma VI. Uluslararası Sosyal Bilgiler Eğitimi Sempozyumu(USBES)'nda sözlü bildiri olarak sunulmuştur.
} 


\section{GİRİ̧̧}

Bireyler doğumlarından ölümlerine kadar, yaşamları boyunca, toplumla olan etkileşimlerini sürdürürler. Bir bireyin toplumun bir üyesi haline gelmesinde ve kişiliğinin oluşmasında ailesi ilk etkileri oluşturur. Ancak aile, bireyi yetiştirmede çeşitli nedenlerle yetersiz kalmaktadır. Ailenin bu eksikliğini tamamlamada en büyük görev eğitim kurumlarına düşmektedir (Kondu ve Sakar, 2013). Bireylerin ulusal statüye çıarılmasında eğitimin önemine vurgu yapan Rousseau, gelecekte bireylerin üzerine düşen görevlerini yerine getirmelerinde onlara verilecek olan eğitimin ailelerin insafına bırakılmayacak kadar önemli bir durum olduğuna dikkat çekmiştir ve bireylere verilecek olan eğitimin ise kamu desteğiyle verilmesi gerektiğini ifade etmiştir (Şimşek, Küçük ve Topkaya, 2012). Nitekim bireyin etkili vatandaş olarak yetişmesi için gereksinim duyulan bilgi, beceri, değer ve kazanımlar okul dışı öğrenmelere kıyasla eğitim kurumlarında daha sistematik bir biçimde kazandırıldığı ifade edilebilir (Topkaya ve Coşkun, 2016).

İlkçağlardan itibaren demokratik toplumlara ulaşıllncaya kadar vatandaşlık eğitimi devletlerin gündeminde yer almış ve yer almaya da devam etmektedir (Köksal, 2007). Vatandaşlık eğitimi, ilk olarak devletine faydalı vatandaşlar yetiştirmeyi amaçlarken günümüzde ise vizyonu değişerek çevresine duyarlı, empati becerileri gelişmiş, yaratıcı ve eleştirel düşünerek sorgulayabilen, katıllımcı, işbirliği içinde çalışabilen etkili bireyler yetiştirmeyi amaçlar hale gelmiştir (Acun, Demir ve Göz, 2010). Nitekim Topkaya (2016) günün şartlarına uygun davranışlar sergileyen bireylerin yetiştirilmesi için en uygun yerlerin eğitim kurumları olduğu ifade edilmiştir.

Bir vatana ait olmanın yanında o vatanın ortak değerleri, yasal düzenlemeleri, örf ve adetleri gibi toplumsal düzenlemelerine uyum sağlama davranışı ile "vatandaşlık" kavramı ifade edilebilir (Uğurlu, 2011). Vatandaşlık eğitiminin tanımı ise, öğrencilerin devlet, hukuk ve siyaset bilgilerini geliştiren bilinçli veya açık çaba şeklinde yapılabilir (Hoge, 2002).

Eğitim aracıllı̆ıyla bireylere, toplumun diğer bireyleriyle ve devletle olan ilişkilerinde gözetecekleri hak ve görevlerin öğretilmesi gerekmektedir. Ülkedeki bütün vatandaşların vatandaşlık görevleri için gerekli olan bilgi, beceri ve değerleri benzer ölçülerde sahip olması benzer bir eğitim süreçleriyle mümkün olabilmektedir (Akbaş, 2008).

Öğrenciler, etkili vatandaşlık eğitiminde vatandaşlıkla ilgili bilgi, beceri ve değerleri kazanmalıdırlar. Bunun yanında etkili bir vatandaşlık eğitimiyle hak, eşitlik, özgürlük, sosyal katılım gibi siyasal kavramların gerekliliği de kavranmalıdır (Ersoy, 2016). Öğrencilere, vatandaşlıkla ilgili yeterlikler, erken yaşlarda başlanarak ve düzeylerine uygun şekilde verilmelidir. Kazandırılması gereken bilgi, beceri ve değerler öğretim programları aracılı̆̆ıyla eğitim kurumları arayıcılığıyla kazandırılmalıdır (Patrick, 2003).

Eğitim sistemleri, vatandaş yetiştirme rolünü çeşitli derslere yükleyerek yerine getirmeyi amaçlamaktadır. Sosyal bilimlere ait dersler bu amaçlara uygun içeriklere sahiptirler (Hoge, 2002; İbret ve Avc1, 2017: 47). Bu bağlamda ilk ve ortaokullarda vatandaş eğitimiyle ilgili içerikler sosyal bilgiler derslerinde yoğun şekilde işlenmiştir.

Toplumda sosyal bir birliktelik sağlama arayışının sonucunda sosyal bilgiler dersi ortaya çıkmıştır. Toplumlarda meydana gelen sosyal hareketlilikleri ve değişimleri kendi amaçları doğrultusunda kontrol edebilmeyi amaçlayan devletler, sosyal bilim disiplinlerini “etkili vatandaş” yetiştirmede normatif bir kurallar dizgesi halinde ilköğretim ve ortaöğretim okullarına bir ders olarak koymuşlardır. Sosyal bilgiler dersi Türkiye'de de vatandaşlık eğitimi konusunda mihver bir ders olarak yer almaktadır (Kara, Yavuz ve Şimşek, 2012).

Türkiye'de ilk ve ortaokullarda vatandaşl1k konusunun öğretilebileceği en uygun ders Sosyal Bilgiler dersidir (Çermik, Çalısoğlu ve Tahiroğlu, 2016). Türkiye'de verilen Sosyal Bilgiler eğitiminin temel amacı da dünyadaki örnekleri gibi vatandaşlık eğitimi üzerinedir. Devletlerin sahip olduğu ideolojiye uygun vatandaşlar yetiştirme amacı eğitime bu görevi yüklemektedir (İbret ve Avc1, 2017:47). Vatandaşlık eğitiminin devletler açısından ne kadar önemli olduğunu, bu devletlerin eğitim sistemlerinde vatandaşlık eğitimine verilen değere bakarak anlayabiliriz (Kan, 2009). 
Vatandaşlık eğitiminin temelleri ilk ve ortaokul düzeyinde verilen eğitimlerle atılmaktadır. Bu çerçevede ilkokullarda sınıf öğretmeni ve ortaokullarda sosyal bilgiler öğretmenleri bu sorumluluğu üstlenmektedirler. Bu nedenle vatandaşlık eğitimini verecek öğretmen adaylarının vatandaşlık ve vatandaşlık eğitimi hakkındaki görüşleri önem taşımaktadır.

\subsection{Araştırmanın Amacı}

Bu çalışmada Sınıf ve Sosyal bilgiler öğretmen adaylarının vatandaşlık ve vatandaşlık eğitimi hakkındaki görüşlerinin değerlendirilmesi amaçlanmıştır. Bu amaçla çalışmada aşağıdaki sorulara cevap aranmaya çalışılmıştır.

1. Vatandaşlık kavramını nasıl tanımlarsınız?

2. Vatandaşlıkla ilgili konularda hangi kaynaklardan yararlanırsınız?

3. Vatandaşlıkla ilgili konularda yeterliliğiniz hakkında düşünceleriniz nelerdir?

4. İleride vatandaşlık eğitimi ile ilgili derslerinizde ne tür etkinlikler yaparsınız?

5. Türkiye'de eğitim hayatınız boyunca almış olduğunuz vatandaşlık eğitiminin yeterliliği hakkında düşünceleriniz nelerdir?

6. Türkiye'de verilen vatandaşlık eğitimine ilişkin önerileriniz nelerdir?

\section{YÖNTEM}

$\mathrm{Bu}$ araştırma Sınıf ve Sosyal bilgiler öğretmen adaylarının vatandaşlık ve vatandaşlık eğitimi hakkındaki görüşlerini belirlemeye yönelik bir çalış̧madır. Çalışma betimsel tarama modelinde nitel bir araştırmadır. Öğretmen adaylarının görüşlerini belirlemek için görüşme tekniğinden yararlanıldığından dolayı çalışma nitel bir araştırmadır. Nitel araştırma kendine özgü veri toplama tekniklerinin kullanıldığı (gözlem, görüşme, doküman analizi vb.), olayları ve algıları gerçekçi ve bütüncül olarak ortaya koymaya çalışmaktadır (Yıldırım ve Şimşek, 2008: 45). Grupların veya bireylerin sosyal ya da beşeri problemlere yükledikleri anlamları ortaya çıararak anlam kazandırmaya çalışan bir yöntemdir (Creswell, 2016: 4).

\section{1. Çalışma Grubu}

Çalışma grubunun seçimi amaçlı örnekleme tekniklerinden ölçüt örnekleme yöntemine göre yapılmıştır. Ölçüt örnekleme, çalışmaya katılan katılımcıların belirlenen bazı ölçütleri karşılayanların çalışmaya dahil edilmesidir (Büyüköztürk, vd., 2014: 91). Bu örnekleme yönteminin asıl amacı önceden tespit edilen ölçütleri (Yıldırım ve Şimşek, 2013: 140) karşılayanların çalışmaya katılmasını sağlamaktır.

Araştırmanın çalışma grubunu 2016-2017 eğitim öğretim yllında bir devlet üniversitesinde eğitim gören 4. sınıf sosyal bilgiler ve sınıf eğitimi anabilim dalı (toplam 75) öğrencileri oluşturmaktadır. Bunlardan 46’sı kız 27’si erkektir. Çalışma grubuna ilişkin demografik bilgiler tabloda verilmiştir.

Tablo1. Çalışma Grubunun Demografik Analizi

\begin{tabular}{llll}
\hline Bölüm & K1z & Erkek & Toplam \\
\hline Sosyal Bilgiler Eğitimi & 16 & 19 & 35 \\
\hline Sinıf Ĕ̆itimi & 32 & 8 & 40 \\
\hline Toplam & $\mathbf{4 6}$ & $\mathbf{2 7}$ & $\mathbf{7 5}$ \\
\hline
\end{tabular}

\subsection{Veri Toplama Arac1}

Sınıf ve Sosyal bilgiler öğretmen adaylarının vatandaşlık ve vatandaşlık eğitimi hakkındaki görüşlerinin alındığı bu çalışmada araştırmacılar tarafindan yarı yapılandırılmış mülakat formu kullanılması kararlaştırılmışır. Öncelikli olarak ilgili literatür ve konuyla ilgili yapılan diğer çalışmalar gözden geçirilmiş ve araştırmada kullanılmak üzere 10 soru hazırlanmıştır. Ardından konuyla ilgili 3 uzmandan hazırlanan soruların incelenmesi istenmiştir. İnceleme sonunda uzmanlar, araştırma kapsamında 6 sorunun kullanılması gerektiği yönünde karar birliğine varmışlardır. Uzman görüşleri neticesinde yarı yapılandırılmış mülakat formuna son şekli verilmiştir. Veri toplama aracı olarak yarı yapılandırılmış mülakat formu kullanılmıştır. Bu mülakatlar tam yapılandırılmış ve yapılandırılmamış mülakat formlarının arasındadır (Merriam, 2013: 88). Bu tür mülakatlarda her soru önceden dikkatli bir şekilde kurgulanarak hazırlanmalıdır. (Patton, 2014: 344). 


\subsection{Verilerin Analizi}

Çalısmada elde edilen verilerin analizinde içerik analizi kullanılmıştır. İçerik analizinde asıl amaç verileri anlamlandırabilecek kavramlara ve bağlantılara ulaşmaktır. İçerik analizde elde edilen veriler daha ayıntılı bir şekilde incelenir (Yıldıım \& Şimşek, 2013: 259). İçerik analizi sosyal bilimlerde sıklıkla kullanılan insanın doğası ve davranışları üzerinde dolaylı yollarla çalışmaya imkân tanıyan bir tekniktir (Büyüköztürk, Çakmak, Akgün, Karadeniz, \& Demirel, 2014: 246). Balc1 (2015: 221) söylenen ve yazılan verilerin anlaş1lır bir şekilde kodlanarak anlatılmasıdır.

Verilerin analizinde frekans olarak öğretmen aday sayısı alınmış olup, “f” kodlara ait frekansı ifade etmektedir. Etik ilkeler gereği insanların kimliklerine ilişkin tanımlayıcı bilgiler doğrudan veya dolaylı olarak verilmemelidir (Şimşek ve Yıldırım, 2013: 122). Bu nedenle öğretmen adaylarına ilişkin kodlar oluşturulmuştur. SNF1 veya SOS1 öğretmen adaylarına verilen kodlardır. Örneğin SNF7 sınıf öğretmenliği yedinci sıradaki öğrenciyi, SOS7 Sosyal bilgiler öğretmenliği yedinci sıradaki öğrenciyi temsil etmektedir.

\section{BULGULAR}

Buraya Sınıf ve Sosyal bilgiler öğretmen adaylarına yöneltilen “vatandaşlık kavramını nasıl tanımlarsınız?” sorusuna verilen cevaplar Tablo 2'de ayrıntılı bir şekilde gösterilmiştir.

Tablo 2. Vatandaşlık tanımına ilişkin bulgular

\begin{tabular}{|c|c|c|c|}
\hline Tema & & & f \\
\hline \multirow{18}{*}{ 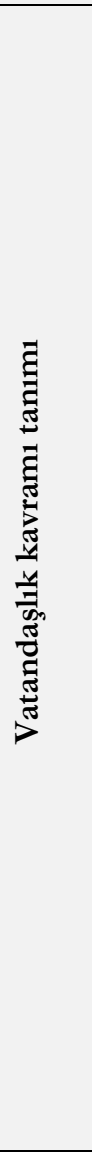 } & Kod & & \\
\hline & Aidiyet & $\begin{array}{l}\text { SNF1, SNF3, SNF6, SNF8, SNF10, SNF14, SNF16, SNF19, SNF20, SNF21, } \\
\text { SNF30, SNF31, SNF33, SNF35, SNF39, SOS7, SOS8, SOS13, SOS14, SOS17, } \\
\text { SOS21, SOS22, SOS26, SOS27, SOS28, SOS31, SOS32, SOS33, SOS35 }\end{array}$ & 29 \\
\hline & Hak & $\begin{array}{l}\text { SNF5, SNF6, SNF8, SNF11, SNF17, SNF22, SNF24, SNF25, SNF27, SNF28, } \\
\text { SNF29, SNF32, SNF36, SNF37, SNF38, SNF40, SOS1, SOS5, SOS7, SOS9, } \\
\text { SOS14, SOS17, SOS19, SOS20, SOS27, SOS29 }\end{array}$ & 26 \\
\hline & Sorumluluk & $\begin{array}{l}\text { SNF1, SNF4, SNF8, SNF9, SNF12, SNF18, SNF22, SNF23, SNF27, SNF32, } \\
\text { SOS1, SOS2, SOS5, SOS10, SOS17, SOS20, SOS24 }\end{array}$ & 17 \\
\hline & Görev & $\begin{array}{l}\text { SNF3, SNF4, SNF9, SNF12, SNF18, SNF22, SNF27, SNF38, SOS2, SOS4, } \\
\text { SOS9, SOS11, SOS12, SOS17, SOS20, SOS24, SOS26 }\end{array}$ & 17 \\
\hline & Bağlilik & $\begin{array}{l}\text { SNF1, SNF2, SNF7, SNF26, SNF34, SNF39, SOS3, SOS5, SOS12, SOS15, } \\
\text { SOS16, SOS22, SOS32 }\end{array}$ & 13 \\
\hline & Hürriyet & SNF5, SNF11, SNF25, SNF28, SNF29, SNF36, SNF40 & 7 \\
\hline & Hukuk & SNF17, SNF36, SOS1, SOS7, SOS12, SOS25, SOS29 & 7 \\
\hline & Kural (Yasa) & SNF35, SOS1, SOS11, SOS23, SOS25, SOS29 & 6 \\
\hline & İnsani Değer & SNF17, SOS6, SOS16, SOS30, SOS31 & 5 \\
\hline & Yurttaşlık & SNF14, SNF32, SOS6, SOS21 & 4 \\
\hline & Politik & SNF15, SOS18, SOS33, SOS34 & 4 \\
\hline & Duyarlilik & SNF24, SOS28, SOS29, & 3 \\
\hline & Ahlaklı olma & SOS3, SOS4, SOS31 & 3 \\
\hline & Eşitlik & SNF20, SNF38, SOS35 & 3 \\
\hline & Vatanını sevme & SOS6, SOS15 & 2 \\
\hline & Problem çözme & SNF24 & 1 \\
\hline & Demokrasi & SNF13, & 1 \\
\hline
\end{tabular}

\section{*Bazı öğretmen adayları birden fazla koda ifade belirttiği için kaynak toplamı katılımcı sayısından fazla} olabilir.

Tablo 2 incelendiğinde "vatandaşlı kavramı tanımı" teması altında 17 adet kod oluşturulmuştur. En fazla oluşturulan kod 29 katılımcı cevabiyla aidiyet, daha sonra sırasıyla 26 katılımcı cevabiyla görev, 17 katılımc1 cevabiyla bağhlık, 17 katılımcı cevabiyla sorumluluk, 13 katılımc1 cevabiyla bağhllke,7 katılımc1 cevabiyla bürriyet, 6 katılımcı cevabiyla kural(yasa), 5 katılımcı cevabıyla insani değer, 4 katılımcı cevabıyla yurttaşlık, 4 katılımc1 cevabiyla politik, 3 katılımc1 cevabiyla duyarllhk, 3 katılımc1 cevabiyla ablakl olma, 3 katılımc1 cevabıyla Eșitlik, 2 katılımcı cevabıyla vatanım sevme, 1 katılımcı cevabıyla problem çözme, 1 katılımcı cevabıyla demeokrasidir. Bu doğrultuda, öğretmen adaylarının ifadelerine ilişkin dikkat çeken görüşlerden bazıları örnek olarak aşağıda belirtilmiştir:

Aidiyet:

"Ait olduğu ülke, vatan smorlar içinde o bölgenin toplumuna uyum sağlayıp bir düzen içinde yasayan insanlar kapsayan kavramder." (SNF10).

"Bir kişinin ait olduğu toplumdaki yeridir.” (SOS26). 
Görev- Sorumluluk:

"Ülkesinin refabr için üzerine düşen görevleri hakekryla yerine getirmek ve birçok görev ve sorumlulukla çeşitli haklara sahip olmakttr." (SNF22).

"Devlet ile bireyin bir birine karşı yapması gereken görev ve sorumluklar bir araya toplayan kurallara denir." (SOS24)

Bağllilk:

"Bir bireyin devletine, milletine bağhllh̆̆ın göstermis olduğu etkin bir kavramder." (SNF1).

"Bir devlete ya da ülkeye tüm bağlarla bağlanmaktır." (SOS5).

Sınıf ve Sosyal bilgiler öğretmen adaylarına yöneltilen "vatandaşlıkla ilgili konularda hangi kaynaklardan yararlanırsınız? ” sorusuna verilen cevaplar Tablo 3’te ayrıntılı bir şekilde gösterilmiştir.

Tablo 3. Öğretmen adaylarının vatandaşlıkla ilgili konularda yararlandıkları kaynaklara ilişkin bulgular

\begin{tabular}{|c|c|c|c|}
\hline Tema & & & f \\
\hline \multirow{12}{*}{ 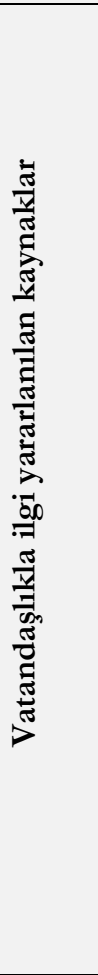 } & Kod & & \\
\hline & İnternet siteleri & $\begin{array}{l}\text { SNF2, SNF3, SNF4, SNF7, SNF8, SNF9, SNF13, SNF14, SNF15, } \\
\text { SNF16, SNF17, SNF18, SNF20, SNF24, SNF26, SNF27, SNF28, } \\
\text { SNF29,SNF30, SNF31, SNF33, SNF34, SNF36, SNF40, SOS1, SOS2, } \\
\text { SOS5, SOS8, SOS10, SOS13, SOS15, SOS16, SOS21, SOS22, SOS29, } \\
\text { SOS31, SOS33,SOS35, }\end{array}$ & 38 \\
\hline & Ders Kitapları & $\begin{array}{l}\text { SNF2, SNF3, SNF6, SNF8, SNF9, SNF24, SNF26, SNF27, SNF30, } \\
\text { SNF31, SNF34, SNF38, SNF39, SOS2, SOS3, SOS4, SOS5, SOS6, SOS7, } \\
\text { SOS8, SOS9, SOS10, SOS11, SOS12, SOS13, SOS15, SOS16, SOS17, } \\
\text { SOS18, SOS20, SOS21, SOS22, SOS30, SOS32, SOS33, SOS34,SOS35, }\end{array}$ & 36 \\
\hline & KPSS Kaynakları & $\begin{array}{l}\text { SNF4, SNF5, SNF11, SNF12, SNF17, SNF19, SNF21,SNF28, SNF29, } \\
\text { SNF30, SNF32, SNF33, SNF36, SNF37, SNF38, SNF39, SNF40, SOS3, } \\
\text { SOS5, SOS8, SOS13, SOS14, SOS15, SOS16, SOS20, SOS23, SOS24, } \\
\text { SOS25, SOS26, SOS33 }\end{array}$ & 29 \\
\hline & Anayasa & $\begin{array}{l}\text { SNF4, SNF5, SNF6, SNF7, SNF8, SNF10, SNF20, SNF22, SNF23, } \\
\text { SNF35, SNF38, SOS2, SOS10, SOS11, SOS17, SOS20 }\end{array}$ & 16 \\
\hline & Eğitmenler & $\begin{array}{l}\text { SNF13, SOS1, SOS4, SOS8, SOS9, SOS12, SOS14, SOS19, SOS23, } \\
\text { SOS24, SOS25, SOS26 }\end{array}$ & 12 \\
\hline & Kitle İletişim Araçları & SNF1, SNF15, SNF21, SOS1, SOS11, SOS12, SOS15, SOS16, SOS20 & 9 \\
\hline & Ansiklopedi & SNF3, SNF14, SNF21, SNF27 & 4 \\
\hline & Dergi & SNF18, SOS29 & 2 \\
\hline & Toplum & SOS12, SOS31 & 2 \\
\hline & Konferans & SOS16 & 1 \\
\hline & Aile & SOS1 & 1 \\
\hline
\end{tabular}
olabilir.

Tablo 3 incelendiğinde "vatandaşlıkla ilgili yararlanilan kaynaklar" temas1 altında 11 adet kod oluşturulmuştur. En fazla oluşturulan kod 38 katılımcı cevabiyla internet, daha sonra sirasıyla 36 katılımc1 cevabiyla ders kitaplar, 29 katılımc1 cevabiyla KPSS kaynaklar, 16 katılımc1 cevabiyla Anayasa 12 kat1lımc1 cevabiyla eğitmenler, 9 katılımcı cevabiyla kitle iletisim araçlar, 4 katılımcı cevabıyla ansiklopedi, 2 katılımc1 cevabiyla toplum, 1 katılımc1 cevabıyla konferans, 1 katılımc1 cevabıyla ailedir. Bu doğrultuda, öğretmen adaylarının ifadelerine ilişkin dikkat çeken görüşlerden bazıları örnek olarak aşağıda belirtilmiştir:

\section{Internet siteleri}

"Internet, okul notlar." (SNF31).

"Internet, çesitli kitap ve TV den yaralanyorum.” (SOS15).

Ders Kitaplar1

"KPSS kitaplar, vatandaşlik ders kitaplar.” (SNF30).

“Okulda gördü̈̆̈̈m vatandaşlı ders kitabından ve KPSS kitaplarndan.” (SOS3).

\section{KPSS Kaynaklanı}

"Güncel anayasa kitaplar, KPSS genel kültür ve genel yetenek kitaplar" (SNF21).

“Genellikle KPSS kitaplarndan yararlanyorum. Bunun yanında ders kitabr ve internetten de yaralanyorum.” (SOS5).

Sınıf ve Sosyal bilgiler öğretmen adaylarına yöneltilen "vatandaşlıkla ilgili konularda yeterliliğiniz bak.k.ndaki düşünceleriniz nelerdir?’' sorusuna verilen cevaplar Tablo 4’te ayrıntılı bir şekilde gösterilmiştir. 
Ufuk ŞIMSŞEK, Fatih TIKMAN, Esat YILDIRIM \& Mehmet ŞENTÜRK

Tablo 4. Öğretmen adaylarının vatandaşlıkla ilgili konularda yeterliliklerine ilişkin bulgular

\begin{tabular}{|c|c|c|c|}
\hline \multirow[t]{2}{*}{ Tema } & \multicolumn{3}{|c|}{ Yeterli olduğunu düşünüyorum } \\
\hline & Kod & & \\
\hline \multirow{25}{*}{ 离 } & $\begin{array}{l}\text { Vatana bağllilı (zarar verecek faaliyette bulunmama, } \\
\text { fayda sağlama) }\end{array}$ & $\begin{array}{l}\text { SNF3, SNF22, SNF23, SNF28, SOS1, SOS3, } \\
\text { SOS15 }\end{array}$ & 7 \\
\hline & Vatandaşılı haklarına önem verme & SNF5, SOS1, SOS3, SOS16 & 4 \\
\hline & İnsanlarla bağ kurma birliktelik sağlama & SNF20, SOS23, SOS28 & 3 \\
\hline & Ahlaki değerlere önem verme & SOS3, SOS23, SOS31 & 3 \\
\hline & Donanımlı olmaya önem verme & SNF29 & 1 \\
\hline & Okul dersleri yeterliliği & SOS27 & 1 \\
\hline & Aileden alınan eğitim & SOS23 & 1 \\
\hline & \multicolumn{3}{|c|}{ Kısmen yeterli olduğunu düşünüyorum } \\
\hline & Kod & & \\
\hline & Okuyarak geliştiriyorum & SNF26, SNF34, SNF35, SOS4, SOS13, SOS34 & 6 \\
\hline & KPSS çalışmamdan dolayı & SNF27, SNF33,SNF36, SNF39 & 4 \\
\hline & Ezbere dayalı eğitim & SNF18, SNF25, SOS20 & 3 \\
\hline & Üniversitede aldığım desten dolay1 & SNF27 & 1 \\
\hline & Kalıp bilgilerle & SNF32 & 1 \\
\hline & Kanunlardaki değişiklileri takip edememe & SOS5 & 1 \\
\hline & Sadece kendi hakkımı biliyorum & SNF37 & 1 \\
\hline & \multicolumn{3}{|c|}{ Yeterli olduğunu düşünmüyorum } \\
\hline & Kod & & \\
\hline & Bilgi eksikliği & $\begin{array}{l}\text { SNF2, SNF4, SNF7, SNF8, SNF11, SNF12, } \\
\text { SNF13, SNF14, SNF15, SNF21, SNF24, } \\
\text { SNF40, SOS7, SOS9, SOS10, SOS12, SOS18, } \\
\text { SOS21, SOS22, SOS24, SOS25, SOS29, SOS33, } \\
\text { SOS35 }\end{array}$ & 24 \\
\hline & Alınan eğitimden verim alamama & $\begin{array}{l}\text { SNF19, SNF30, SNF40, SOS2, SOS6, SOS8, } \\
\text { SOS21, SOS24, SOS26, SOS29 }\end{array}$ & 10 \\
\hline & Günlük yaşamla ilişskilendirememe & SNF10, SNF9, SOS17, SOS24 & 4 \\
\hline & İlgimi çekmeme & SNF6, SOS21, SOS25, SOS30 & 4 \\
\hline & Kulaktan dolma bilgilerle ögrrenme & SNF1, SNF4, SNF40 & 3 \\
\hline & Sürü Psikolojisiyle hareket etme & SNF1 & 1 \\
\hline & Insanlığa katkı sağlayamama & SOS32 & 1 \\
\hline
\end{tabular}
olabilir.

*Bazı ögretmen adayları birden fazla koda ifade belirttiği için kaynak toplamı katılımcı sayısından fazla

Tablo 4 incelendiğinde "vatandaşlikla ilgili konularda yeterlilik" teması altında 3 adet alt tema oluşturulmuştur. Yeterli olduğunu düşünüyorum alt teması altında en fazla oluşturulan kod 7 katılımcı cevabiyla vatanına bağhlhk, daha sonra sirasiyla 4 katılımc1 cevabiyla vatandaşlı haklarna önem verme, 3 katilımc1 cevabiyla insanlarla bă̆ kurma birliktelik sağlama, 3 katılımc1 cevabıyla ablaki değerlere önem verme 1 katılımc1 cevabiyla donanıml olmaya önem verme, 1 katılımcı cevabiyla okul derslerinin yeterlilï̆i, 1 katılımc1 cevabiyla aileden alman eğitimdir. Kısmen yeterli olduğunu düşünüyorum alt teması altında en fazla oluşturulan kod 6 katılımc1 cevabiyla okuyarak gelistiriyorum daha sonra sirasıyla 4 katılımcı cevabiyla KPSS çalışmamdan dolayı, 3 katılımc1 cevabiyla ailedir. Yeterli olduğunu düşünmüyorum alt teması altında en fazla oluşturulan kod 24 katılımc1 cevabiyla bilgi eksikliği, 10 katılımc1 cevabıyla alman eğitimden verim alnamama, 4 katılımc1 cevabiyla günlük yaşamla ilişkilendirilememe, 4 katılımc1 cevabiyla ilgimi çekmememe, 3 katılımc1 cevabiyla kulaktan dolma bilgilerle ögrenme, 1 katılımcı cevabıyla sürü psikolojisiyle hareket etme, 1 katılımc1 cevabıyla insanliğa katkr sağlayamamadır. Bu doğrultuda, öğretmen adaylarının ifadelerine ilişkin dikkat çeken görüşlerden bazıları örnek olarak aşağıda belirtilmiştir:

\section{Yeterli olduğunu düşünüyorum}

Vatana bağlllik (zarar verecek faaliyette bulunmama, fayda sağlama)

"Bence yeterli olduğunu düş̈̈n̈̈yorum. V atandaşlıkta en önemli husus devletini, vatanm, milletini bayrağgn can gönülden sevmektir. Ben de bu bususa dikekat ediyorum." (SNF3).

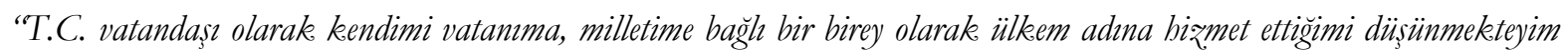
bu yüzden yeterli.” (SOS15).

\section{Vatandașlik haklarına önem verme}

"Yeterli çünkü kişi hak ve bürriyetlerine önem vermeye çallşıorum ve vatandaşllk görevlerimi yerine getirmeye çalssyorum.” (SNF3).

"Vatandaşlke hakekinda yeterli bilgiye sahip olduğumu düş̈̈n̈̈yorum gerektiğinde kendi haklarmı ve diğer insanlarn baklarm koruyabilirim." (SOS16). 


\section{Kismen yeterli olduğunu düşünüyorum}

\section{Okuyarak gelistiriyorum}

"Orta düzeyde olduğumu düs̈̈nüyorum. Kendimi geliștirmek için okumaya araştırmaya devam ediyorum. Bu ülkenin vatandaşı olduğum için hake ve sorumluluklarmı öğrenmeye çalışıyorum.” (SNF35).

"Kısmen yeterli olduğunu düsünüyorum. Çünkü okudü̆umuz kitaplar ve internet bilgilerimizi artırmamızda yardımo oldu." (SOS13).

\section{KPPS çalıșmamdan dolayı}

"Vatandaşlık ile ilgili KPPS haz̧rlandı̆̆ım süreçten beri bilgi konusunda yeterli olmaya başladım. Fakat hala yeterli olmadiğı görüş̈̈ndeyim.” (SNF27).

"Bu seneye kadar bu konuda yeterliliğim olduğunu düsünmüyorum. Ancak bu sene KPPS çalışmaya başlaynca bilmediğim birçok konu oldü̆unu ögrendim ve bu konular ögrenmeye başladım.” (SNF33).

\section{Yeterli olduğunu düşünmüyorum}

\section{Bilgi eksikliği}

"Vatandaşlıkla ilgili konularda maalesef yeterli olduğumu düs̈̈̈müyorum. Anayasayı bilmemem bu yeterliliğimim nedenlerinden biri.” (SNF4).

“Gerek eğitim yetersizliği gerek kendi bilgi birikim eksikliğim kendimi yeterli görmüyorum.” (SOS21).

Sınıf ve Sosyal bilgiler öğretmen adaylarına yöneltilen "ileride vatandaşlık eğitimi ile ilgili derslerinizde ne tür etkinlikler yaparsımı?? " sorusuna verilen cevaplar Tablo 5'te ayrıntılı bir şekilde gösterilmiştir.

Tablo 5. Vatandașlıkla ilgili derslerde yapılacak etkinliklere ilișkin bulgular

\begin{tabular}{|c|c|c|c|}
\hline \multirow{19}{*}{ 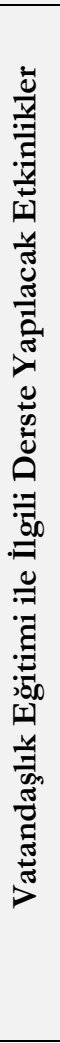 } & Kod & & \\
\hline & Drama & $\begin{array}{l}\text { SNF1, SNF2, SNF6, SNF13, SNF14, SNF17, SNF20, } \\
\text { SNF21, SNF23, SNF28, SOS1, SOS5, SOS7, SOS9, SOS11, } \\
\text { SOS20, SOS21, SOS28, SOS29, SOS34 }\end{array}$ & 20 \\
\hline & Film, video, slayt & $\begin{array}{l}\text { SNF2, SNF6, SNF11, SNF14, SNF20, SOS1, SOS9, SOS16, } \\
\text { SOS19, SOS20, SOS26, SOS27, SOS29, SOS30, SOS34 }\end{array}$ & 15 \\
\hline & Günlük hayatla ilişkilendirme & $\begin{array}{l}\text { SNF5, SNF8, SNF24, SNF25, SNF27, SNF29, SNF30, } \\
\text { SNF39, SNF40, SOS14, SOS18, SOS21, SOS29 }\end{array}$ & 13 \\
\hline & Yaparak- Yaşayarak & $\begin{array}{l}\text { SNF3, SNF4, SNF22, SNF34, SOS2, SOS4, SOS12, SOS15, } \\
\text { SOS17, SOS20, SOS22, SOS23, SOS24 }\end{array}$ & 13 \\
\hline & Somutlaştırma & $\begin{array}{l}\text { SNF5, SNF7, SNF8, SNF23, SNF26, SOS2, SOS7, SOS24, } \\
\text { SOS26, SOS34 }\end{array}$ & 10 \\
\hline & Örnek olay & SNF2, SNF29, SNF35, SOS3, SOS17, SOS21, SOS29 & 7 \\
\hline & Çevresi ile farkındalık oluşturma & SNF9, SNF11, SNF15, SOS31, SOS33 & 5 \\
\hline & Anlatım Yöntemi & SOS13, SOS15, SOS18, SOS25, SOS32 & 5 \\
\hline & Yakından uzağa ilişkisi & SNF5, SNF12, SNF14, SOS2 & 4 \\
\hline & Beyin Firtınası & SNF16, SOS17, SOS29, SOS30 & 4 \\
\hline & Tartışma & SOS17, SOS26, SOS30, SOS35 & 4 \\
\hline & Rol oynama & SNF7, SNF11, SOS29 & 3 \\
\hline & Soru cevap & SNF21, SOS22, SOS35 & 3 \\
\hline & Gezi & SOS2, SOS11 & 2 \\
\hline & D-Y kartlar1 & SNF17 & 1 \\
\hline & Model olma & SOS10 & 1 \\
\hline & Gazete & SOS26 & 1 \\
\hline & Zihin haritalar1 & SOS20 & 1 \\
\hline
\end{tabular}

*Bazı öğretmen adayları birden fazla koda ifade belirttiği için kaynak toplamı katılımcı sayısından fazla olabilir.

Tablo 5 incelendiğinde "vatandaşlikla ilgili derslerde yapılacak etkinlikler" teması altında 18 adet kod oluşturulmuştur. En fazla oluşturulan kod 20 katılımcı cevabıyla drama, daha sonra sırasıyla 15 katılımc1 cevabiyla film, video, slayt, 13 katılımc1 cevabiyla günlük yaşamla iliskilendirme, 13 katılımc1 cevabiyla yaparakyaşayarak, 10 katılımc1 cevabiyla somutlastırma, 7 katılımc1 cevabiyla örnek olay, 5 kat1lımc1 cevabiyla çevresiyle farkındalı olusturma, 5 katılımc1 cevabiyla anlatım yöntemi, 4 katılımc1 cevabiyla yakından uzağa ilişkisi, 4 katılımc1 cevabiyla beyin firtınası, 4 katılımcı cevabiyla tartısma, 3 katılımc1 cevabiyla rol oynama, 2 katılımc1 cevabiyla gezi, 1 katılımcı D-Y kartlar, 1 katılımcı cevabiyla model olma, 1 katılımcı cevabiyla gazete, 1 katılımcı cevabiyla zibin haritalarıdır. Bu doğrultuda, öğretmen adaylarının ifadelerine ilişkin dikkat çeken görüşlerden bazıları örnek olarak aşağıda belirtilmiştir.

$\underline{\text { Drama }}$

"Bu tür derslerde Drama'nn kullanulması etkili olacaktır." SNF1 
Ufuk ŞİMŞEK, Fatih TIKMAN, Esat YILDIRIM \& Mehmet ŞENTÜRK

"İy bir vatandas yetistirmek için sosyal aktivite olarak drama uygulanabilir." SNF13

"Soyut bir derstir soyut dersi somutlaşttrmak için drama yaptorrm." SOS7

“Öğrencilerin yeterli vatandaş olabilmeleri için önemli seyleri drama yöntemiyle canlandirarak anlatırdim.” SOS28

Film, video, slayt

"Ë̆itici film ve videolar izletirim.” (SNF6).

"Vatandaşlıkla ilgili video, film ve sunu iə̧letirim. Böylelikle bu konuda çocuklarda farkindahk olușturmus olurum." (SNF11).

"Etkinlik olarak iyi birey nasil olunur? Bunu slayt ve video kullanarak ögrencilere kazandırmay a çalsşırdım.” (SOS16).

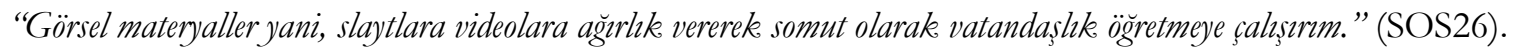

Günlük hayatla ilisskilendirme

"Güncel konular ele alarak çocuğun neyin içinde olduğunu, ne bakekenda bilgi sabibi olması gerektiğ̈ni, yaşadiğı toplumun nasil bir durumda olduğunun farkında olmasin sağlayacak etkinlikler yapıla bilir.” (SNF9).

“Gerçek olaylar ile ilgili örnekler vermeye çalısııdım.” (SNF25).

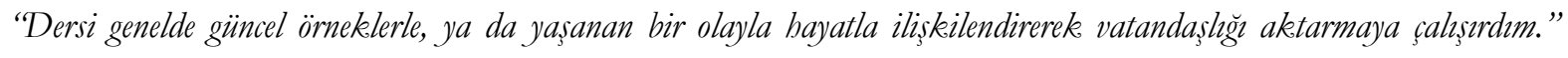
(SOS21).

Sınıf ve Sosyal bilgiler öğretmen adaylarına yöneltilen "Türkiye'de eğitim hayatınız boyunca almış olduğunuz vatandaşlık eğitiminin yeterliliği hakkında düşünceleriniz nelerdir?” sorusuna verilen cevaplar Tablo 6'da ayrıntılı bir şekilde gösterilmiştir.

Tablo 6. Vatandaşlıkla ilgili alınan eğitimin etkililiğine ilișkin bulgular

\begin{tabular}{|c|c|c|c|}
\hline Tema & & Etkili & $\mathrm{f}$ \\
\hline \multirow{16}{*}{ 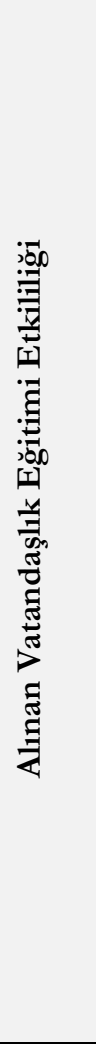 } & Kod & & \\
\hline & Eğitim hayatımız boyunca aldık & SNF5, SNF10, SOS18 & 3 \\
\hline & Verimli eğitim alma & SOS27, SOS32 & 2 \\
\hline & $\begin{array}{l}\text { Donanımlı ebeveyn ve öğretmen } \\
\text { sahip olma }\end{array}$ & SNF16, & 1 \\
\hline & \multicolumn{3}{|c|}{ Etkili değil } \\
\hline & Kod & & \\
\hline & Nitelikli eğitim verilmemesi & $\begin{array}{l}\text { SNF13, SNF15, SNF22, SNF39, SNF40, SOS5, SOS13, SOS15, } \\
\text { SOS17, SOS19, SOS20, SOS21, SOS22, SOS24, SOS28, , SOS29, } \\
\text { SOS35 }\end{array}$ & 18 \\
\hline & Teorik öğretildiği için & $\begin{array}{l}\text { SNF2, SNF4, SNF8, SNF18, SNF20, SNF26, SNF3,SNF21, } \\
\text { SOS1, SOS2, SOS3, SOS14, SOS17, SOS20, SOS23, SOS31, } \\
\text { SOS33, SOS34 }\end{array}$ & 18 \\
\hline & Ders saatinin yetersizliği & $\begin{array}{l}\text { SNF6, SNF17, SNF19, SNF21, SNF23, SNF25, SNF28, SNF29, } \\
\text { SNF32, SNF35, SNF36, SNF38, SOS8, SOS15 }\end{array}$ & 14 \\
\hline & Temelimiz sağlam değil & $\begin{array}{l}\text { SNF4, SNF9, SNF11, SNF12, SNF14, SNF20, SNF34, SNF39, } \\
\text { SNF40 }\end{array}$ & 9 \\
\hline & $\begin{array}{l}\text { Öğretmenlerin konu hakkında } \\
\text { yetersizliği }\end{array}$ & SNF27, SNF33, SOS6, SOS7, SOS8, SOS12, SOS22 & 7 \\
\hline & Gerçek hayatla uyuşmamas1 & SNF6, SNF11, SOS3, SOS17, SOS21, SOS29, SOS30, & 7 \\
\hline & Ezbere dayalı olduğu için & SNF1, SNF3, SOS4, SOS10, SOS20, SOS26 & 6 \\
\hline & $\begin{array}{l}\text { Dersin öneminim ülkemizde } \\
\text { kavranamaması }\end{array}$ & SNF24, SNF27, SNF37, SOS20 & 4 \\
\hline & Konuların tekrara girmesi & SNF30, SNF31, & 2 \\
\hline & Araştırma eksikliği & SOS2 & 1 \\
\hline
\end{tabular}

*Bazı öğretmen adayları birden fazla koda ifade belirttiği için kaynak toplamı katılımcı sayısından fazla olabilir.

Tablo 6 incelendiğinde "Alınan vatandaşlıkla eğitiminin etkililiğð” teması altında 2 adet alt tema oluşturulmuştur. Etkili alt teması altında toplam 3 adet kod oluşturulmuştur. Bu alt tema altında en fazla oluşturulan kod 3 katılımcı cevabıyla eğitim hayatımı , boyunca aldık, daha sonra sırasıyla 2 katılımcı cevabiyla verimli eğitim alma, 1 katılımcı cevabıyla donammlı ebeveyn ve ögretmene sahip olmadır. Etkili değil alt teması adı altında toplam 10 kod oluşturulmuştur. Bu alt tema altında en fazla oluşturulan kod 18 katılımcı cevabiyla nitelik:li eğitim verilmemesi ve yine 18 katılımc1 cevabiyla teorik ögretildiği için, daha sonra sırasiyla 14 katılımc1 cevabiyla ders

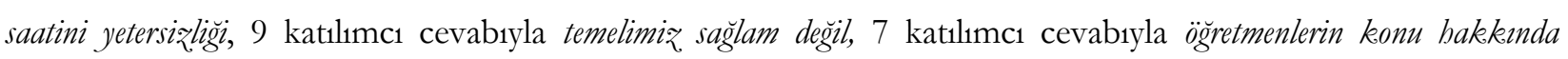
yetersiz̨liği, 7 katılımc1 cevabiyla gerçek hayatla uyusmama, 6 katılımc1 cevabiyla ę̧bere dayalı olduğn için, 4 katılımc1 cevabiyla dersin öneminim ülkemizde kavranamaması, 2 kat1lımc1 cevabiyla konularn tekrara girmesi, 1 katılımc1 cevabıyla Araştırma eksikliğgidir. Bu doğrultuda, öğretmen adaylarının ifadelerine ilişkin dikkat çeken görüşlerden bazıları örnek olarak aşağıda belirtilmiştir. 


\section{Etkili}

Eğitim hayatımız boyunca aldık

“ilkögretim 8. simiftan bu zamana kadar vatandaşllk eğitimi alyyoruz:” (SNF5).

"Ortaokul döneminde vatandaşlı dersi olarak haftada iki saat olarak aldı. Lisede Milli güvenlik dersi olarak aldrk." (SNF10).

\section{Verimli eğitim alma}

"Vatandaşllk konusunda verimli bir şekilde eğitim verilmeye çalş̧llyyor." (SOS27).

\section{Etkili değil}

\section{Nitelikli eğitim verilmiyor}

"Yeterli ve nitelikeli bir eğitim verilmiyor. Şuana kadar aldiğım dersler sınav geçmek içindi." (SOS24).

Teorik öğretildiği için

"Aldiğımı vatandaşlı derslerinin pratik olmadiğın tamamen teoriye dönük olduğunun derslerin sadece işlenmek için işlendiğini ifade edebilirim. Yani derslerin hayatımıza etkisi yok." (SOS17).

\section{Ders saatini yetersizliği}

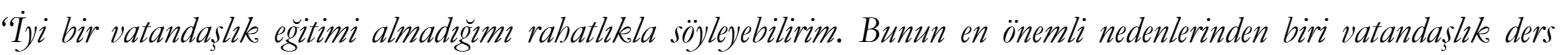
saatinin az olmasidrr."(SNF24).

"Dersler yetersiz, dersin içeriği çok ders saat sayısı ądır." (SOS8).

Sınıf ve Sosyal bilgiler öğretmen adaylarına yöneltilen "Türkiye'de verilen vatandaşlık eğitimine ilişkin önerileriniz nelerdir?”' sorusuna verilen cevaplar Tablo 7'de ayrıntılı bir şekilde gösterilmiştir.

Tablo 7. Vatandaşıı eğitimi ile ilgili önerilere ilişkin bulgular

\begin{tabular}{|c|c|c|c|}
\hline \multicolumn{4}{|c|}{ Tema } \\
\hline \multirow{17}{*}{ 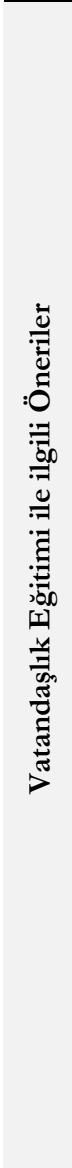 } & Kod & & \\
\hline & Günlük hayatla uyuşan vatandaşılk eğitimi verilmeli & $\begin{array}{l}\text { SNF5, SNF7, SNF8, SNF9, SNF17, SNF21, SNF22, SNF25, } \\
\text { SNF28, SNF31, SNF39, SNF40, SOS17, SOS21, SOS24, } \\
\text { SOS26, SOS30 }\end{array}$ & 17 \\
\hline & Uygulamalı vatandaşılık eğitimi verilmeli & $\begin{array}{l}\text { SNF3, SNF4, SNF18, SNF19, SNF20, SNF25, SNF39, SOS2, } \\
\text { SOS7, SOS17, SOS20, SOS23, SOS26, SOS34 }\end{array}$ & 13 \\
\hline & Kalıı ve etkili vatandaşılı eğitimi verilmeli & $\begin{array}{l}\text { SNF11, SNF18, SNF19, SNF22, SNF23, SNF31, SNF36, } \\
\text { SNF37, SNF38, SOS28, SOS29, SOS33 }\end{array}$ & 12 \\
\hline & $\begin{array}{l}\text { İnsanların sahip oldukları hakları kavratan } \\
\text { vatandaşlık eğitimi verilmeli }\end{array}$ & $\begin{array}{l}\text { SNF2, SNF29, SNF33, SNF35, SNF39, SNF40, SOS1, SOS6, } \\
\text { SOS25 SOS32 }\end{array}$ & 10 \\
\hline & $\begin{array}{l}\text { Bu dersin önemi kavratacak vatandaşlık eğitimi } \\
\text { verilmeli }\end{array}$ & $\begin{array}{l}\text { SNF10, SNF12, SNF14, SNF15, SNF30, SOS3, SOS12, SOS27, } \\
\text { SOS29, SOS33 }\end{array}$ & 10 \\
\hline & Vatandaşlık eğitimi ders saatinin artırılması & $\begin{array}{l}\text { SNF21, SNF24, SNF27, SOS5, SOS8, SOS9, SOS12, SOS29, } \\
\text { SOS33, SOS35 }\end{array}$ & 9 \\
\hline & $\begin{array}{l}\text { Vatandaşlık eğitimi daha küçük yaşlardan } \\
\text { başlanarak verilmeli }\end{array}$ & SNF31, SNF38, SOS12, SOS14, SOS15, SOS18 & 6 \\
\hline & $\begin{array}{l}\text { Daha modern yöntem ve tekniklerle vatandaşlk } \\
\text { derslerinin işlenmesi }\end{array}$ & SNF26, SNF30, SOS4, SOS8, SOS11, SOS12 & 6 \\
\hline & Pratik bilgiler içeren vatandaşılı eğitimi verilmeli & SNF7, SNF8, SNF13, SOS1, SOS4 & 5 \\
\hline & $\begin{array}{l}\text { Konun uzmanları tarafindan vatandaşlık eğitimi } \\
\text { verilmeli }\end{array}$ & SNF12, SNF24, SNF36, SOS10 & 4 \\
\hline & $\begin{array}{l}\text { Ezbere dayalı olamayan vatandaşlık eğitimi } \\
\text { verilmeli }\end{array}$ & SNF3, SNF34, SOS21, SOS26 & 4 \\
\hline & Bireyi temel alan vatandaşlık eğitimi verilmeli & SNF1, SNF5, SOS16, SOS23 & 4 \\
\hline & $\begin{array}{l}\text { İhtiyaçlarımız doğrultusunda vatandaşlık eğitimi } \\
\text { verilmeli }\end{array}$ & SNF6, SOS12, SOS32 & 3 \\
\hline & Hoşgörü temelli vatandaşlık eğitimi verilmeli & SNF9 & 1 \\
\hline & Diğer derslerle ilişkilendirilmeli & SOS8 & 1 \\
\hline & $\begin{array}{l}\text { Vatandaşlık eğitimi üzerine çok fazla çalışmalar } \\
\text { yapplmalı }\end{array}$ & SNF35 & 1 \\
\hline
\end{tabular}

\section{*Bazı öğretmen adayları birden fazla koda ifade belirttiği için kaynak toplamı katılımcı sayısından fazla} olabilir.

Tablo 7 incelendiğinde "Vatandaşlık eğ̈itimi ile ilgili öneriler" teması altında 16 adet kod oluşturulmuştur. En fazla oluşturulan kod 17 katulımcı cevabıyla günlük hayatla uyuşan vatandaşlı eğitimi verilmeli, daha sonra sırasıyla 13 katılımc1 cevabiyla uygulamah vatandaşhk eğitimi verilmeli, 12 katılımc1 cevabiyla kahıc ve etkili vatandaşlı eğitimi verilmeli, 10 katılımcı cevabıyla insanlarn sahip olduklar baklar kavratan vatandaşlık eğitimi verilmeli, 10 kat1lımc1 cevabıyla bu dersin önemi kavratacak vatandaşlı eğitimi verilmeli, 9 katılımc1 cevabıyla vatandassllk eğitimi ders saatinin

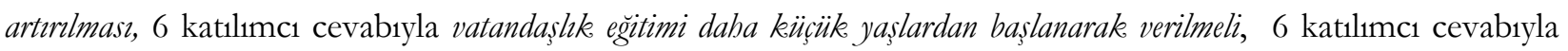
daha modern yöntem ve tekniklerle vatandaşllk derslerinin işlenmesi,5 katıllımcı cevabiyla pratik bilgiler içeren vatandaşlık. eğitimi verilmeli, 4 katılımcı cevabiyla konunun użmanlar tarafından vatandaşlı eğitimi verilmeli, 4 katıllımcı cevabiyla 
ę̧ere dayah olamayan vatandaşlı eğitimi verilmeli,4 kat1lımc1 cevabiyla bireyi temel alan vatandaşlı eğitimi verilmeli, 3 katılımc1 cevabiyla ibtiyaçlarımı doğrultusunda bir vatandaşlı eğitimi verilmeli,1 katılımc1 D-Y hosgörü temelli vatandaşlık eğitimi verilmeli, 1 katılımc1 cevabıyla diğer derslerle iliskilendirilmeli, 1 katılımc1 cevabıyla vatandaşlhk eğitimi üzerine çok faそla çalıs̆malar yapılmalıdır. Bu doğrultuda, öğretmen adaylarının ifadelerine ilişkin dikkat çeken görüşlerden bazıları örnek olarak aşağıda belirtilmiştir.

\section{Günlük hayatla uyuşan vatandaşlık eğitimi verilmeli}

"Bilgiler daha anlamlı hale getirilmeli, anlatılanlar havada kalmamalı. Günlük hayatta karşılaşabileceüimiz, bilgiler verilmeli." (SNF8).

"Verilen vatandaşllk eğitimi günlük hayatla iliskili olmal." (SNF9).

Uygulamalı vatandaşlık eğitimi verilmeli

"Yaparak yaşayarak ögrenciler eğitime dâbil edilmeli. Sinfflarda uygulamalar yapılmalı.” (SOS17).

“Bu derste somutta aktarm yapılmalı. Ögrencilere yaparak yasayarak davranıs kazandirma amaçlanmaludrr.”( SNF18). $\underline{\text { Kalıcı ve etkili vatandașlık eğitimi verilmeli }}$

'Türkiye'de verilen vatandaşllk eğitimini yetersiz buluyorum. Vatann önemi üzerinde daba fazla durulmal vatandaşlarn

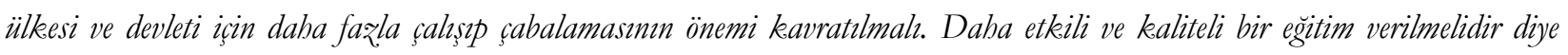
düsünüyorum.” (SOS33).

"Vatandaşlı. eğitimi üzerine daha etkili bir program yapılması gerektiğini düş̈nüyorum.” (SNF23).

İnsanların sahip oldukları hakları kavratan vatandaşlık eğitimi verilmeli

“Sabip olduklar görev ve sorumluluklar bilen vatandaslar yetiștirilmelidir.” (SOS25).

"Öğrencilerimiz haklarm bilen bireyler olarak yetiștirmememiz gerektig̈ini düs̈̈̈nüyorum.” (SNF2).

\section{TARTIŞMA ve SONUÇ}

Günümüzde toplumlar, çağdaş uygarlık seviyesine ulaşabilmek için modern dünyaya ayak uydurabilen, farkındalığ1 yüksek (Gibson ve ark., 2008) çözüm üretebilen, bilim ve teknolojinin sunduğu imkânlardan yararlanabilen aktif vatandaşlara ihtiyaç duymaktadır. Etkili vatandaşların yetiştirilmesinde aileye büyük sorumluluklar yüklenmiş olsa da bu sorumluluğun önemli bir kısmını okullar üstlenmektedir. Okullarda bu eğitimi temel seviyede verme görevi sınıf öğretmenleri ve sosyal bilgiler öğretmenlerine aittir. Bu nedenle ileride hayat bilgisi ve sosyal bilgiler dersinin öğretiminden sorumlu olacak ve bu eğitimi verecek olan sınıf ve sosyal bilgiler öğretmenleri adaylarının vatandaşlık ve vatandaşlık eğitimi hakkındaki görüşleri önemli bir noktayı oluşturmaktadır.

Yapılan bu çalışmada elde edilen bulgular neticesinde şu sonuçlara ulaşılmıştır:

Öğretmen adaylarının çoğunluğu vatandaşlık tanımı yaparken aidiyet, hak, sorumluluk, görev, hürriyet ve bağll1ık kavramlarına vurgu yapmışlardır. Öğretmen adaylarının verdikleri cevaplar konu hakkındaki bakış açılarının sınırlılığı ortaya koymaktadır. Bu durum Yiğit’in (2017) sosyal bilgiler öğretmen adaylarının vatandaşlık algısını belirlemeye çalıştığı araştırmanın sonuçlarıyla benzerlik göstermektedir.

Öğretmen adaylarının vatandaşlık eğitimiyle ilgili kullandıkları kaynakları daha çok internet siteleri, KPSS kaynakları, ders kitapları ve anayasa oluşturmaktadır. Yiğit (2017) sosyal bilgiler öğretmen adayları ile ilgili yapmış olduğu araştırmasında, öğretmen adaylarının vatandaşlık ile ilgili en sık yararlandıkları kaynaklar arasında "sosyal medya" ve "internet” sonucuna ulaşmıştır. Yapılan araştırmamızda da benzer sonuçlara ulaşılmıştır. Buradan hareketle bilgi ve iletişim teknolojilerinin hız kazandığ1 günümüzde bireylerin gerek günlük yaşamlarında gerekse okul hayatında önemli bir yere sahip olan teknolojik araçlardan yararlanılması tezini ortaya koymaktadır. Sosyal medya ve internet kullanımına yönelik teknolojinin gücünden yararlanılması bilgi edinmeye ve ders başarısına olumlu katkı sağlayacağı düşünülmektedir.

Öğretmen adaylarının vatandaşlıkla ilgili konularda çoğunlukla kendilerini yetersiz olarak gördükleri göze çarpmaktadır. Yetersiz gören öğretmen adaylarının çoğunluğu bu yetersizliklerinin 
Ufuk ŞİMŞEK, Fatih TIKMAN, Esat YILDIRIM \& Mehmet ŞENTÜRK vatandaşlık haklarını ve hukuki kuralları bilmemelerinden (bilgi eksikliğinden), aldıkları eğitimden verim alamadıklarından ve gördükleri vatandaşlık eğitiminin günlük yaşamla ilişkilendiremediğinden kaynakladığını söylemişlerdir. Benzer şekilde Çermik, Çalışoğlu ve Tahiroğlu (2016) ve Ceylan (2014)'in yaptıkları çalışmalarda öğretmenlerin vatandaşlık konularında kendilerini yetersiz gördükleri sonucuna ulaşmışlardır. Yine öğretmen adaylarının bir kısmı kendilerini kısmen yeterli hissederken çok az bir kısmı kendini yeterli görmektedir. Kısmen yeterli görenler bu eksiklerini KPSS çalışmalarıyla ve okuyarak kapatmaya çalıştıklarını dile getirmişlerdir. Yeterli görenler ise bu yeterliliklerinin nedenlerini; vatana bağl1 kalarak zarar verecek faaliyetlerde bulunmadan uzak durma, vatanı karşılıksız gönülden sevme, insanlarla bă̆ kurma ve birliktelik sağlamak için gösterdikleri çabadan kaynaklandığının vurgusunu yapmışlardır. Yani kişisel çaba, ilgi ve vatan sevgisi nedeniyle kendilerini geliştirdiklerini belirtmişlerdir. Vatandaşlık dersi konularının somut yöntemlerle içselleştirilmediğinden dolay1 ve verilen eğitimin ciddi bir şekilde önemsenmemesi, yüzeysel veriliyor olmasından dolayı dersin başarıya ulaşamamasında etkili olduğu düşünülmektedir. Bunun için dersin öğrencilerin aktif bir şekilde katılımını sağlayacak etkinlik temelli uygulamaya dönük olarak verilmesi bu sorunu ortadan kaldırmada etkili olabilir (Er, Ünal ve Özmen, 2013; Sadık ve Sarı, 2012; Yiğittir, 2007).

Öğretmen adayları vatandaşlık eğitimiyle ilgili derslerinde daha çok dramadan, günlük hayatla ilişkilendirmeye yönelik etkinliklerden, somutlaştırmaya yönelik etkinliklerden, film ve videolardan yararlanacaklarından bahsetmişlerdir. Öğrencilerin vatandaşlık eğitimi ile ilgili derslerde kazanımlara ulaşılabilmeleri için öğrenme öğretme sürecine aktif bir şekilde katılımlarını sağlayacak günlük hayatla ilişkili somut yöntemlerin kullanılması gerektiği yapılan çalışmada tespit edilmiştir. İnsan hakları eğitiminde yaratıcı dramanın yöntem olarak kullanıldı̆̆ı sınırlı sayıda araştırmada, insan hakları eğitiminin kazanımlarına ulaşıldığını görmek mümkündür (Ulubey ve Gözütok, 2015; Kaya, 2002). Buradan hareketle gerek alanyazında drama ve diğer yöntemlerin kazanımlara ulaşması noktasında gerekse yapılan çalışmada drama ve diğer yöntemlerin öğrencilerin derse katılımlarını aktif bir şekilde sağlayacağı, öğrencilerin bilgilerini kalıcı kılacağı ve dersi ilgi çekici hale getireceğinden dolay1 vatandaşlık eğitimi gibi derslerde kullanılmasının yararlı ve gerekli olacağı düşünülmektedir.

Öğretmen adaylarının çoğunluğu eğitim hayatları boyunca aldıkları vatandaşlık eğitiminin etkililiğinin yetersiz olduğuna dikkat çekmişlerdir. Buna etki eden nedenleri dile getirirken birçoğu gerçek hayatla uyuşan bir eğitim alamadıklarını, nitelikli eğitim verilmediğini, ders saatinin yetersiz olduğunu, uygulamalar yapılmayarak teorik olarak öğretim yapıldığını ve sağlam bir temel atılmadığını belirtmişlerdir. Kondu ve Sakar (2013) vatandaşlık eğitimi verme amacı taşıyan derslerin saatinin arttırılması ve etkinliklere daha fazla yer verilmesinin bu derslerin konularının öğrenciler tarafindan daha çok içselleştirilmesinde etkili olacağını ifade etmektedir. Yapılan birçok araştırma, vatandaşlık eğitimine yönelik verilen derslerin amaçlarına yeterince ulaşamadığını ortaya koyar niteliktedir (Arıkan, 2002; Güdücü, 2008; Güven, 2010; İnan, 2005; Kıvanç, 2003; Toraman, 2012; Uyangör, 2007, Ulubey ve Gözütok, 2015). Vatandaşlık eğitimine yönelik derslerin amacına ulaşamamasının nedeni olarak birçok araştırmada öğrenme ortamlarının öğrenciyi aktif hale getirecek şekilde düzenlenmemesi; ders sürecinde düz anlatım, soru cevap ve tartışma gibi yöntemlerin ağırlıklı olarak kullanılması ve diğer yöntemlerle anlatımın zenginleştirilmemesi gösterilmektedir (Arıkan, 2002; Aydeniz, 2010; Candan, 2006; Çıplak, 2002; Dolanbay, 2011; Güdücü, 2008; Karaman-Kepenekçi, 2005; Kıvanç, 2003; Özbek, 2004; Toper, 2007; Uyangör, 2007). Ayrıca Vatandaşlık dersine yönelik öğrencilerde olumlu tutumların oluşturulması da son derece önem arz etmektedir. Nitekim insanları harekete geçiren ve onları davranışlara yönelten temel unsur benimsemiş oldukları tutumlardır. Bu 
Ufuk ŞİMŞEK, Fatih TIKMAN, Esat YILDIRIM \& Mehmet ŞENTÜRK bağlamda vatandaşlık dersine yönelik öncelikli olarak öğrencilere olumlu bir tutumun kazandırılması gerekmektedir. Bu bağlamada farklı türden öğretim materyallerinden faydalanılarak ders sürecinin zenginleştirilmesi gerekmektedir. Topkaya ve Şimşek (2015) tarafindan ortaya konulan çalışmada eğitici çizgi romanlar aracıllı̆ğyla işlenen vatandaşlık dersine yönelik öğrencilerin olumlu bir tutuma sahip oldukları saptanmıştır.

Vatandaşlık eğitimiyle ilgili öneride bulunmaları istenen öğretmen adaylarının çoğunluğunun önerileri şu şekildedir; Günlük hayatla uyuşan, kalıcı, etkili bir vatandaşlık eğitiminin verilmesi ile beraber bu eğitimin uygulamalı bir şekilde olması gerektiğini ve bu dersin önemini kavratacak bir vatandaşlık eğitiminin verilmesinin yerinde olacağını belirtmişlerdir.

Bu sonuçlara göre, vatandaşlık eğitimi temelli derslerin ders saatlerinin arttırılması; ders içeriklerinin vatandaşlık becerilerinin geliştirilmesinde daha etkili olacak şekilde düzenlenmesi; derslerin işlenme sürecinde, öğrenci merkezli öğretim yöntem ve tekniklerinden daha çok yararlanılması; vatandaşlık becerililerin geliştirilmesinde sınıf dışı etkinlikler, dırama, örnek olay incelemesi, gözlem, görüşme gibi etkinliklerin gerçekleştirilmesi; vatandaşlık eğitiminin önemine dikkat çekecek çalışmaların arttırılması önerilmektedir.

\section{KAYNAKÇA}

Acun, İ., Demir, M., \& Göz, N. L. (2010). Öğretmen adaylarının vatandaşlık yeterlilikleri ile eleştirel düşünme becerileri arasındaki ilişki. Sosyal Bilgiler Eğitimi Araștırmalar Dergisi, 1(1), 107-123.

Arıkan, F. (2002). Vatandaşllk ve insan haklarn eğitimi dersi eğitim programınn öğretmen görüsleri doğrultusunda değerlendirilmesi. (Yayınlanmamış yüksek lisans tezi). Sakarya Üniversitesi, Sakarya.

Aydeniz, D. (2010). İlkögretim 4. 5. simf sosyal bilgiler dersinin insan haklar ve demokrasi eğitimindeki işlevselliği. (Yayınlanmamış yüksek lisans tezi). Sakarya Üniversitesi, Sakarya.

Büyüköztürk, S.., Çakmak, E. K., Akgün, Ö. E., Karadeniz, Ș., \& Demirel, F. (2014). Bilimsel araştırma yöntemleri (17 b.). Ankara: Pegem.

Candan, R. (2006). Illkögrretim 2. kademe 7. ve 8. simfta okutulan vatandaşlı. ve insan baklar eğitimi dersinin ögretimi ve ögretiminde karşılaşılan güçlïkler (Ardahan Örneği). (Yayınlanmamış yüksek lisans tezi). Selçuk Üniversitesi, Konya.

Ceylan, Ş. (2014) Okul öncesi öğretmenlerinin dünya vatandaşlı̆g eğitimi ile ilgili görüşleri, Kuramsal Ĕ̆itimbilim Dergisi, 7(1), 78-93.

Creswell, J. W. (2016). Araştırma deseni, nitel, nicel ve karma yöntem yaklaşımları. S. B. Demir (Çeviri edt:). Ankara: Eğiten Kitap.

Çermik, F., Çalışoğlu, M., \& Tahiroğlu, M. (2016). Sınıf öğretmenlerinin küresel vatandaşlık eğitimi ile ilgili görüşlerinin incelenmesi. Electronic Turkish Studies, 11(3), 775-790.

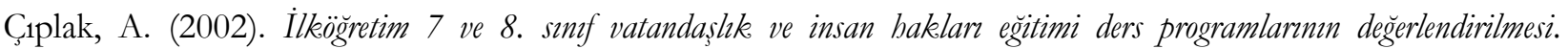
(Yayınlanmamıss yüksek lisans tezi). Ankara Üniversitesi, Ankara.

Dolanbay, H. (2011). İlkögrretim Sosyal Bilgiler Öğretmenliği Programinda ögrenim gören ögrretmen adaylarmm insan haklar ve demokrasi dersinin işlenişine iliş̧kin görüsleri. (Yayınlanmamış yüksek lisans tezi). İnönü Üniversitesi, Malatya.

Er, H., Ünal, F., \& Özmen, C. (2013). 8. sınıf vatandaşlık ve demokrasi eğitimi dersinin 4. sınıfa alınmasına ilişkin görüşler üzerine bir araştırma. International Journal of Social Science, 6(8), 179-196.

Ersoy, A. F. (2016). Vatandaşlık ve demokrasi eğitimi dersine ilişkin sosyal bilgiler öğretmenleri ve öğrencilerinin alg1s1. İnönü Üniversitesi Eğitim Fakülttesi, 17(3), 67-83. do1: 10.17679/iuefd.17345163

Gibson, K.L, Rimmington G.M. \& Landwehr-Brown M. (2008). Developing Global Awareness and Responsible World Citizenship With Global Learning, Roeper Review 30(2), 11-23.

Güdücü, H. S. (2008). İlkögretim programlarnda yer alan vatandaşlı ve insan baklar eğitimi dersine ilişkin ögretmen algissna yönelik. Manisa örneği. (Yayınlanmamış yüksek lisans tezi). Celal Bayar Üniversitesi, Manisa.

Güven, S. (2010). İlkögretim birinci kademede vatandaşlık eğitimi üzerine bir durum şalışması. (Yayımlanmamış doktora tezi). Gazi Üniversitesi, Ankara.

Hoge, J. D. (2002). Character education, citizenship education, and the social studies. The Social Studies, 93(3), 103-108. do1: 10.1080/00377990209599891

İbret B. Ü. \& Avc1. E. K. (2017). Sosyal bilgiler ögretiminde kimlik algisı. R. Turan ve H. Akdağ (Ed.). Sosyal bilgiler öğretiminde yeni yaklaşımlar III (38-53). Ankara: Pegem Akademi. 
İnan, K. (2005). İlkögretim 7. sinf vatandaşlık ve insan haklar eğitimi dersi ögretim programinda ifadesini bulan temel hak ve özgürlüklerin kazamlma düzeyi. (Yayınlanmamış yüksek lisans tezi). Gazi Üniversitesi, Ankara.

Kan, C.. (2009) Sosyal bilgiler eğitiminde küresel vatandaşlık, Pamukkeale Üniversitesi Eğitim Fakültesi Dergisi, 26, 25-30.

Kara, C., Topkaya, Y. ve Şimşek, U. (2012). Aktif vatandaşlık eğitiminin sosyal bilgiler programındaki yeri. Zeitschrift für die Welt der Türken/Journal of World of Turks, 4(3), 147-159.

Karaman-Kepenekçi, Y. (2008). Eğitimciler için insan hakları ve vatandaşlık. Ankara: Ekinoks Yayınları.

Kaya, M. (2002). Polisin insan haklar eğitiminde yaratıc drama yönteminin kullanılması. (Yayınlanmamıs yüksek lisans tezi). Ankara Üniversitesi, Ankara.

Kıvanç, Ö. (2003). İlkëğretim insan haklar eğitimi sürecinin Avrupa Konseyi insan haklar eğ̈timi çerçevesinde öğretmenler tarafindan değerlendirilmesi. (Yayınlanmamış yüksek lisans tezi). Çukurova Üniversitesi, Adana.

Kondu, Z., \& Sakar, T. (2013). Vatandaşlık ve demokrasi eğitimi dersi niçin verilir?. Mebmet Akif Ersoy Üniversitesi Eğitim Bilimleri Enstitïsü Dergisi, 2(3), 49-60.

Köksal, H. (2007) İlkçağda Vatandaşlık Eğitimi Olarak Tarih Öğretimi, Kastamonu Eğitim Dergisi, 15(1), 271278.

Merriam, S. B. (2013). Nitel araştırma desen ve uygulama için bir rehber. S. Turan (Çeviri Ed.), Ankara: Nobel.

Özbek, R. (2004). Vatandaşhlk ve insan haklar eğitimi ders amaçlarmın gerçekleşme düzeyi. (Yayımlanmamış doktora tezi). Atatürk Üniversitesi, Erzurum.

Patrick, J. J. (2003). Essential elements of education for democracy: What are they and why should they be at the core of the curriculum in schools? http://www.civiced.org/pdfs/EEOEforDemocracy.pdf adresinden 25.09.2017 tarihinde alınmıştır.

Patton, M. Q. (2014). Nitel araştrma değerlendirme yöntemleri. M. Demir ve S. B. Demir (Çeviri Ed.), Ankara: Pegem Akademi.

Sadık, F. \& Sarı, M. (2012). Çocuk ve demokrasi: ilköğretim öğrencilerinin demokrasi algılarının metaforlar aracıllğıyla incelenmesi. Uluslararası Cumburiyet Eğitim Dergisi, 1(1), 48-62.

Şimşek, U., Küçük, B., \& Topkaya, Y. (2012). Ideologic basıcs of educational policies in republican period. Turkish Studies- International Periodical For The Languages, Literature and History of Turkish or Turkic, 7(4), 2809-2823.

Toraman, Ç. (2012). İlköğretim 8. simf vatandaşllk ve demokrasi eğitimi ders programmmn değerlendirilmesi. (Yayınlanmamış yükssek lisans tezi). Ankara Üniversitesi, Ankara.

Toper, T. (2007). Illkögretim ikinci kademede demokrasi eğitimi: ikinci kademe ögretmenlerinin demokratik tutum ve davramıslar sergileme düzeyleri (Kars ili örneği). (Yayınlanmamış yüksek lisans tezi). Kafkas Üniversitesi, Kars.

Topkaya, Y. (2016). Sosyal bilgiler öğretmenlerinin değer aktarım yaklaşımları hakkındaki görüşlerine ait nitel bir çalışma. Abi Evran Üniversitesi Kırşsehir Ë̈itim Fakültesi Dergisi, 17(1), 637-652.

Topkaya, Y. \& Coşkun, K. (2016). Küresel vatandaşlık bilinci üzerinde sosyal bilgiler öğretim programında yer alan değerlerin etki boyutu. Sosyal Bilimler Dergisi, 6(11), 238-252.

Topkaya, Y., \& Şimşek, U. (2015). Impact of instructional comics on the attitudes towards citizenship and democracy education. Journal of Computer and Education Research, 3(6), 152-167.

Uğurlu, C. T. (2011). Avrupa birliği ülkelerinde ve Türkiye'de vatandaşl1k eğitimi. Elektronik Sosyal Bilimler Dergisi, 10(37), 153-169.

Ulubey, Ö. \& Gözütok, F. (2015). Yaratıcı drama ve diğer etkileşimli öğretim yöntemleri ile geleceğin vatandaşlık, demokrasi ve insan hakları eğitimi. Eğitim ve Bilim, 40 (182), 87-109.

Uyangör, N. (2007). İlkögretim 7. simf Vatandaşlı ve İnsan Haklar Ĕ̈itimi Programınn değerlendirilmesi. (Yayınlanmamış doktora tezi). Hacettepe Üniversitesi, Ankara.

Üstündağ, T. (1997). Vatandaşlik ve insan haklar eğitimi dersinin öğretiminde yaratıc dramanun erisisiye ve derse yönelike ögrenci tutumlarna etkisi. (Yayımlanmamış doktora tezi). Hacettepe Üniversitesi, Ankara.

Yıldırım, A., \& Şimşek, H. (2013). Sosyal bilimlerde nitel araştrma yöntemleri. Ankara: Seçkin.

Yiğit, E.Ö. (2017). Sosyal bilgiler öğretmen adaylarının gözünden vatandaşlık ve türk vatandaşlı̆̆ı, İlkögrretim Online, 16(2), 406-427.

Yiğittir, S. (2007). “İlköğretim 7. Sınıf vatandaşlık ve insan hakları eğitimi dersinin gerçekleşme düzeyi ile ilgili öğrenci görüşleri”. Milli Eğitim Dergisi. Sayı:173.

\section{Citation Information}

Şimşek, U., Tıkman, F., Yıldırım, E. \& Şentürk, M. (2017). Sosyal Bilgiler ve Sınıf Eğitimi Öğretmen Adaylarının Gözünden Vatandaşlık Eğitimi: Nitel Bir Çalışma. Dicle Üniversitesi Ziya Gökalp Eğitim Fakültesi

Dergisi, 32, 913-925. 